\title{
A review of natural products, their effects on SARS-CoV-2 and their utility as lead compounds in the discovery of drugs for the treatment of COVID-19
}

\author{
Robert L. Chapman $(\mathbb{D})^{1} \cdot$ Shridhar V. Andurkar ${ }^{1}$
}

Received: 26 August 2021 / Accepted: 15 November 2021 / Published online: 2 December 2021

(c) The Author(s), under exclusive licence to Springer Science+Business Media, LLC, part of Springer Nature 2021

\begin{abstract}
During the COVID-19 pandemic lasting now for well more than a year, nearly 247 million cases have been diagnosed and over 5 million deaths have been recorded worldwide as of November 2021. The devastating effects of the SARS-CoV-2 virus on the immune system lead to the activation of signaling pathways involved in inflammation and the production of inflammatory cytokines. SARS-CoV-2 displays a great deal of homology with other coronaviruses, especially SARS-CoV and MERS-CoV which all display similar components which may serve as targets, namely the Spike (S) protein, the main protease $\left(\mathrm{M}^{\mathrm{Pro}}\right)$ which is a chymotrypsin-like protease $\left(\mathrm{CL}^{\mathrm{Pro}}\right)$ and RNA-directed RNA polymerase (RdRp). Natural constituents found in traditional herbal medicines, dietary supplements and foods demonstrate activity against SARS-CoV-2 by affecting the production of cytokines, modulating cell signaling pathways related to inflammation and even by direct interaction with targets found in the virus. This has been demonstrated by the application of fluorescence resonance energy transfer (FRET) experiments, assays of cytopathic effect (CPE) and in silico molecular docking studies that estimate binding strength. Glycyrrhizin, flavonoids such as quercetin, kaempferol and baicalein, and other polyphenols are the most common constituents found in Traditional Chinese Medicines that modulate inflammation and cell signaling pathways, and bind viral targets demonstrating valuable effects against SARS-CoV-2. However, the bioavailability of these natural products and their dependence on each other in extracts make it difficult to assess their actual utility in the treatment of COVID-19. Therefore, more can be learned through rational drug design based on natural products and from well-designed clinical trials employing specific doses of standardized combinations.
\end{abstract}

Keywords COVID-19 $\cdot$ SARS-CoV-2 $\cdot$ Herbal $\cdot$ Botanical $\cdot$ Natural Products

$\begin{array}{ll}\text { Abbreviations } \\ \text { ACE2 } & \text { Angiotensin Converting Enzyme Type Two } \\ \text { Ala } & \text { Alanine } \\ \text { AP-1 } & \text { Activator Protein One } \\ \text { Arg } & \text { Arginine } \\ \text { Asp } & \text { Aspartic Acid } \\ \text { BCP } & \beta \text {-Caryophyllene } \\ \text { CB1 } & \text { Endocannabinoid receptor type 1 } \\ \text { CB2 } & \text { Endocannabinoid receptor type 2 } \\ \text { CBC } & \text { Cannabichromene } \\ \text { CBD } & \text { Cannabidiol }\end{array}$

Robert L. Chapman

rchapm@midwestern.edu

1 Department of Pharmaceutical Sciences, Midwestern University College of Pharmacy, 555 31st Street Downers Grove, Downers Grove, IL 60515, United States

$\begin{array}{ll}\text { CBN } & \text { Cannabinol } \\ \text { CBV } & \text { Cannabivarin } \\ \text { CL } & \text { Chymotrypsin-like Protease } \\ \text { COVID- } & \text { Coronavirus Disease, 2019 } \\ 19 & \\ \text { COX-2 } & \text { Cyclooxygenase Two } \\ \text { CPE } & \text { Cytopathic Effect } \\ \Delta^{9}-\text { THC } & \text { Delta-Nine Tetrahydrocannabinol } \\ \text { E } & \text { Envelope Protein } \\ \text { EC }_{50} & \text { Effective Concentration at 50\% Maximal Effect } \\ \text { FRET } & \text { Förster or Fluorescence Resonance Energy } \\ & \text { Transfer } \\ \text { IC } & \text { Inhibitory Concentration at 50\% Inhibition } \\ \text { IFN- } \gamma & \text { Interferon-gamma } \\ \text { IL } & \text { Interleukin } \\ \text { IL-1 } \alpha & \text { Interleukin 1-alpha } \\ \text { IL-1 } \beta & \text { Interleukin 1-beta } \\ \text { iNOS } & \text { Intracellular Nitric Oxide Synthase }\end{array}$


IRF1 Interferon Regulatory Factor One

$\mathrm{Kcal} / \mathrm{mol}$ Kilocalories per mole

$\mathrm{M}^{\text {Pro }} \quad$ Main Protease

MAPK Mitogen Activated Protein Kinase

MCP-1 Monocyte Chemotactic Factor One

MERS- Coronavirus that causes Middle-East Acute

CoV Respiratory Syndrome, in the outbreaks of 2012 and 2015

$\mathrm{Mg} \quad$ Milligram

$\mu \mathrm{M} \quad$ Micromolar

N Nucleocapsid Protein

NAGA N-Acetylglucosamine Amide

NFкB Nuclear Factor Kappa B

NIH National Institutes of Health (U.S.A.)

NO Nitric Oxide

NRP1 Nucleosome Assembly Protein-1 Related Protein-1; Protein neuropilin 1

ORF Open Reading Frame

PASC Post-acute sequalae

PL Pro Papain-like Protease

PPAR Peroxisome-proliferator activated receptor

RNA Ribonucleic Acid

RdRp RNA-directed RNA Polymerase

$\mathrm{S} \quad$ Spike Protein

S1 Spike Protein Segment One

S2 Spike Protein Segment Two

SARS- Coronavirus that causes Systemic Acute

CoV Respiratory Syndrome, in the epidemic of 20022003

SARS- Coronavirus that causes Systemic Acute

CoV-2 Respiratory Syndrome, in the pandemic of 2020-2021

STAT1 Signal Transducer and Activator of Transcription Factor One

TCM Traditional Chinese Medicine

TMPRS- Transmembrane Serine Protease Type Two

$\mathrm{S} 2$

TNF- $\alpha \quad$ Tumor Necrosis Factor-alpha

Trp Tryptophan

TRP Transient cation receptor potential channel

TTP Thymidine Triphosphate

UTP Uridine Triphosphate

\section{Introduction}

The COVID-19 pandemic has been with us now for more than a year. With nearly 247 million cases confirmed and more than 5 million deaths worldwide [1], science continues to learn more and more about how to treat the acute effects of mild, serious and severe infection and long-term sequelae of the virus. At this point there is much concern about the rise of new variants of SARS-CoV-2 that are transmitted more easily from to person. Worries persist about these variants being able to evade the protection offered by new vaccines that have entered the marketplace since late 2020, due to mutations affecting the ability to be recognized by antibodies [2, 3].

SARS-CoV-2 is a betacoronavirus spread by airborne droplets from the respiratory tracts of infected individuals. One reason why severe infection with SARS-CoV-2 is so dangerous is the effect the virus has on the immune system where the lungs are overrun with pro-inflammatory cytokines, often called "cytokine storm." Excessive production and release of cytokines such as Tumor Necrosis Factor Alpha (TNF- $\alpha)$, Interferon Gamma (IFN- $\gamma$ ), and Interleukins (IL-1 $\alpha$, IL-1 $\beta$, IL-2, IL-6, IL-15 and IL-18) is believed to cause the symptoms of moderate to severe COVID-19 infection as well as multiple organ failure and cell death. Signaling pathways involved include the Nuclear Factor Kappa B (NFkB) and IFN pathways and the production of intracellular nitric oxide synthase (iNOS) and nitric oxide (NO) via the interferon regulatory factor 1/ signal transducer and activator of transcription factor 1 (IRF1/STAT1) pathways [4]. Platanitis and Dekker have reviewed the roles of cytokines in these signaling pathways and their relationships to inflammation [5].

The genome of SARS-CoV-2 shares approximately $85 \%$ homology with SARS-CoV, the coronavirus that caused the SARS atypical pneumonia outbreak of 2002-2003. The proteins of SARS-CoV-2 share between $65 \%$ and $97 \%$ homology with those of SARS-CoV. The viral genome of SARS-CoV-2 also demonstrates $35-48 \%$ sequence homology with the envelope and nucleocapsid proteins and surface and membrane glycoproteins of MERS-CoV, the coronavirus that caused the Middle East Respiratory Syndrome outbreaks of 2012 and 2015 [6, 7]. MERS-CoV was originally isolated from the sputum of a man living in the Arabian Peninsula. Genetic analysis of MERS-CoV identified it as a betacoronavirus related to other betacoronaviruses transmitted by bats [8]. Civets and dromedary camels are believed to be the intermediate hosts of MERSCoV [9].

The viral genome of SARS-CoV-2 is a single-stranded (+) RNA polymer coding for a number of proteins in open reading frames (ORFs) that play roles in viral structure, host cell penetration, replication and immunogenicity [10]. As such, SARS-CoV-2 has multiple targets for drug action that researchers are able to exploit in order to slow and diminish the effects of acute infection.

As targets, SARS-CoV-2 produces an envelope protein (E) and a nucleocapsid protein $(\mathrm{N})$, important for viral structure, a main protease $\left(\mathrm{M}^{\mathrm{Pro}}\right)$ which is a chymotrypsinlike protease $\left(\mathrm{CL}^{\mathrm{Pro}}\right)$, a papain-like protease $\left(\mathrm{PL}^{\mathrm{Pro}}\right)$, helicases and RNA-directed RNA polymerase (RdRp), all vital for viral replication. The spike protein $(S)$, is integral for 
viral entry into host cells by interacting with its host cell receptor, angiotensin converting enzyme 2 (ACE2). ACE2 is found on the cells of the pulmonary epithelium as well as many other tissues throughout the body such as kidney, brain, heart and the vasculature [11]. Herbal formulae contain plant materials whose constituents are able to inhibit the proteases, thus inhibiting viral replication, and interact with either the spike protein itself, the spike protein-ACE2 receptor complex or a transmembrane serine protease (TMPRSS2) found on host cells that cleaves the spike protein into S1 and S2 segments to facilitate viral entry into host cells [12].

Such targets can be affected by a number of drugs now being repurposed, such as dexamethasone and tocilizumab, and newly marketed drugs such as remdesivir and favipiravir. Dexamethasone is a glucocorticoid used routinely for its anti-inflammatory properties and tocilizumab is a monoclonal antibody whose target is the IL-6 receptor. It is believed that blocking the IL- 6 receptor could reduce the effects of massive cytokine release during severe infection [13]. Remdesivir and favipiravir are inhibitors of $\mathrm{RdRp}$ found to be effective in the treatment of COVID-19 [13].

Even natural constituents found in herbal medicines, dietary supplements and foods demonstrate activity against SARS-CoV-2 and related coronaviruses, SARS-CoV and MERS [14]. In fact, since the early days of the pandemic clinicians in China have used botanically based Traditional Chinese Medicines as adjunct therapy in the treatment of patients infected with SARS-CoV-2 with remarkable success in decreasing the severity of disease and the length of stay in the hospital [15-24]. However, much remains to be learned from conducting well designed clinical trials of scope and magnitude large enough to explain with certainty that natural medicines, dietary supplements and foods rich in certain phytochemicals have a place in the therapy of COVID-19 [25].

What then are the common phytochemicals and chemical classes of interest from natural sources that have activity against SARS-CoV-2, how do they work, what are their targets and how do we assess their activity? Moreover, why is it important that we understand that this activity exists and how can we exploit it? Physicians in the west may not be ready, able or willing to employ Traditional Chinese Medicine (TCM) as a modality of practice, but if we were to understand the activity of these natural constituents it may be possible to develop new drugs capable of reducing the symptoms and severity of acute infection, reduce the length of stay in hospitals and improve the quality of life in patients infected with SARS-CoV-2 [25]. The NIH Center for Complementary and Integrative Health is also looking for insight into complementary and integrative methods that may even include the use of herbs, dietary supplements and adjustments to the diet in order to mitigate the post-acute sequelae (PASC) of SARS-CoV-2 [26]. In this review, Traditional Chinese Medicines and their most common chemical constituents having activity against coronaviruses, including SARS-CoV-2, are surveyed with discussion relating to their possible mechanisms of action against SARS-CoV-2.

\section{Traditional Chinese medicine (TCM)}

During early 2020 physicians in China, where the outbreak of SARS-CoV-2 originated, began using formulae known and used in TCM to treat viral infections, or what are commonly referred to in TCM as "pestilence" [27]. TCM uses multi-component herbal formulae to achieve treatment of disease. Several formulae were employed that were found to modulate reproducibility of the virus by affecting viral protease enzymes, and modulate the concentration of cytokines in the host, thus affecting the host immune response to the virus [25].

There are at least 116 different, multicomponent TCM formulae and patent medicines composed of more than 215 different plants, plant parts and extracts used in various combinations with one another [25, 28-32]. Although vaccines are now widely used in China and around the world [33], these herbal formulae have been employed as adjuncts in the treatment of patients infected with SARSCoV-2 for various purposes with some success [26]. Many of the plants found in these formulae are not necessarily found commonly as dietary supplements in the US, but many of their chemical constituents that have activity against the targets of SARS-CoV-2, such as kaempferol and quercetin, can be found in dietary supplements. For example, Ginkgo biloba is a popular dietary supplement that is rich in both kaempferol and quercetin [34]. The question then becomes, how can one classify these herbal formulae into a more meaningful subset of information of which to take advantage, chemically? We need to examine the constituents of plants and their activity in inhibiting SARSCoV, MERS-CoV and SARS-CoV-2. Doing so will allow us to learn how these phytochemicals could be used as lead compounds in the development of drugs that can be used to treat and diminish the severity of COVID-19.

\section{Assessment of activity in vitro}

There are many ways to determine and analyze the interactions of various phytochemicals with the targets of SARSCoV-2. FRET-Förster or Fluorescence resonance energy transfer (FRET) experiments use confocal microscopy to analyze the transfer of photons from a donor dye to an acceptor dye over distance through space during excitation 
by light in order to describe the binding strength of a labeled ligand to its labeled target [35]. Binding is often expressed as an $\mathrm{IC}_{50}$ value, the concentration necessary to inhibit $50 \%$ of target activity.

An assay of cytopathic effect (CPE) is a controlled colorimetric assay where cells are incubated in a well plate, exposed to a virus and a suspected antiviral compound in varying concentrations. A log dose-response curve is generated and the $\mathrm{EC}_{50}$ value represents the concentration of the test compound necessary to inhibit $50 \%$ of viral cell death. A lower the $\mathrm{EC}_{50}$ value indicates better ability of the test compound to inhibit viral cell death.

In Silico molecular modeling uses the established crystal structure of viral targets from SARS-CoV-2, or closely related targets of related viruses such as SARS-CoV, docked with a known subset of ligands to establish the binding strength of competitive inhibitors of the target. A variety of targets from both SARS-CoV and SARS-CoV-2 are noted in Table 1 [36-46]. Binding strength is expressed in terms of $\mathrm{kcal} / \mathrm{mol}$. It is best for the binding strength of a test compound to be as close as possible to the binding strength of a known inhibitor or control. It is also important to note that in silico docking is no indication that a compound will absolutely inhibit a target, but it offers a good start for engaging in drug design [47].

\section{Glycyrrhizin}

In reviewing formulae from TCM, the most commonly used herb was Glycyrrhizae radix et rhizoma, from Glycyrrhiza glabra L. and other Glycyrrhiza species, also known in the West as licorice root. This herb, with its anti-inflammatory properties also activates granulocytes, natural killer cells and eosinophils, appears to inhibit both viral entry into host cells and SARS-CoV-2 replication [29, 48-50]. Glycyrrhizin, the major triterpenoid saponin found in licorice root (Fig. 1A), inhibits the binding of SARS-CoV S proteins to ACE2 by binding four residues of ACE2 with a binding free energy similar to flavonoids, thus blocking the ability of SARS-CoV-2 to enter host cells [51]. Glycyrrhizin and its

Table 1 Targets of SARS-CoV and SARS-CoV-2 for in silico binding studies

\begin{tabular}{|c|c|c|c|}
\hline Target & PDB Code & Target & PDB Code \\
\hline SARS-CoV $\mathrm{M}^{\text {Pro }}$ & 1WOF [36] & SARS-CoV-2 $\mathrm{M}^{\text {Pro }}$ & 7K3T [37] \\
\hline SARS-CoV PL ${ }^{\text {Pro }}$ & 2FE8 [38] & SARS-CoV-2 PL Pro & 6W9C [39] \\
\hline SARS-CoV RdRp & 6NUR [40] & SARS-CoV-2 RdRp & 7BV2 [41] \\
\hline SARS-CoV N & 2GIB [42] & SARS-CoV-2 N & $6 \mathrm{YVO}[43]$ \\
\hline SARS-CoV S & 3JCL [44] & SARS-CoV-2 S & $6 \mathrm{VXX}[45]$ \\
\hline Human ACE2 & 7A98 [46] & & \\
\hline
\end{tabular}

aglycone, 18ß-glycyrrhetinic acid, also affect cell signaling pathways involving protein kinase $\mathrm{C}(\mathrm{PKC})$, activator protein 1 (AP1) and NFKB. These two phytochemicals mediate the production of cytokines, inflammation and apoptosis resulting from their production. By decreasing neutrophil infiltration, decreasing nitric oxide synthase and nitric oxide (NO) production, free radical sequestration the production of protective IFN- $\gamma$ and apoptosis increase, while the production of pro-inflammatory cytokines IL-6, IL-10 and TNF- $\alpha$ decrease [28, 48, 50-53]. As used, when taken orally glycerrhizin is dosed as tablets containing approximately $300 \mathrm{mg}$ of glycyrrhizin, capsules containing $150 \mathrm{mg}$ diammonium glycyrrhizinate [31] or as the $1700 \mathrm{mg}$ of the crude herb containing $5.65 \%$ glycyrrhizin. When administered intravenously the dose of glycyrrhizin is approximately $240 \mathrm{mg}$ [51].

In a CPE assay glycyrrhizin's $\mathrm{EC}_{50}$ was $365 \mu \mathrm{M}$ and the $\mathrm{EC}_{50}$ for $18 \beta$-glycyrrhetinic acid (Fig. 1B) was $>20 \mu \mathrm{M}$, but only glycyrrhizin was selective in maintaining cell viability with a selectivity index of $>65$. Interestingly, the 2 -acetimido- $\beta$ $D$-glucopyranosylamine (N-acetylglucosamine amide-NAGA) derivative of glycyrrhizin (Fig. 1C), demonstrated an $\mathrm{EC}_{50}$ value of $40 \mu \mathrm{M}$ with a selectivity index of $>75$, compared to 13 other glycyrrhizin derivatives, 6 of which were potent, but none of which were selective in their cytopathic activity. Presumably, the NAGA derivative binds well with the highly glycosylated S-proteins of SARS-CoV thus increasing the potency of this derivative [54].

Molecular docking studies were carried out in silico with glycyrrhizin and glycyrrhizic acid, and a number of SARSCoV-2 targets. Lower docking scores indicate better binding of the compound with its putative targets. The results of molecular docking studies with glycyrrhizin and glycyrrhizic acid are shown in Table 2 . These encouraging results should shed light into possible modifications relative to the rational design of anti-coronavirus agents based on the triterpenoid saponin, glycyrrhizin $[55,56]$.

\section{Flavonoids and polyphenolics}

Flavonoids (Fig. 2) and other polyphenolic compounds are some of the most widely found chemical compounds in plants used both as medicinal herbs in TCM and other systems of herbal medicine, and from plants eaten in the diet [57]. Flavonoids are polyhydroxylated 2-phenylchromones. They, their glycosides and some bioisosteres demonstrate antiviral activity against SARS-CoV, MERS-CoV and other human coronaviruses as well as influenza A virus [58]. Flavonoids not only stimulate host immune responses to viral exposure; they also suppress excessive inflammatory reactions and modulate autophagy and immunoproteasome effects [57, 59, 60]. 
Fig. 1 A Glycyrrhizin. B Glycyrrhetinic acid. C 2acetamido- $\beta$-D-

glucopyranosylglycyrrhizin

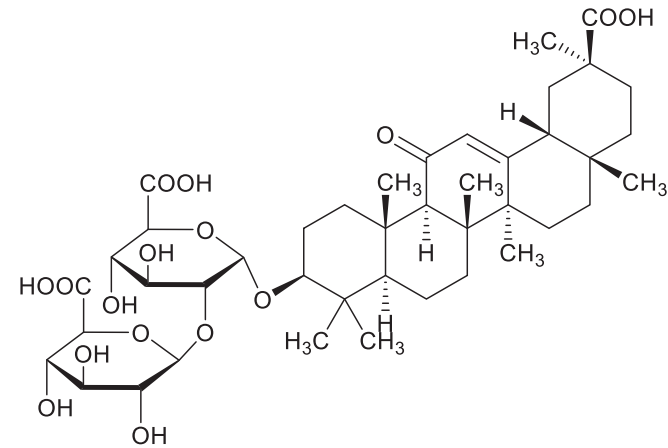

A

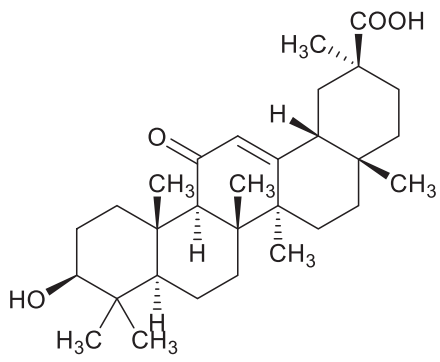

B

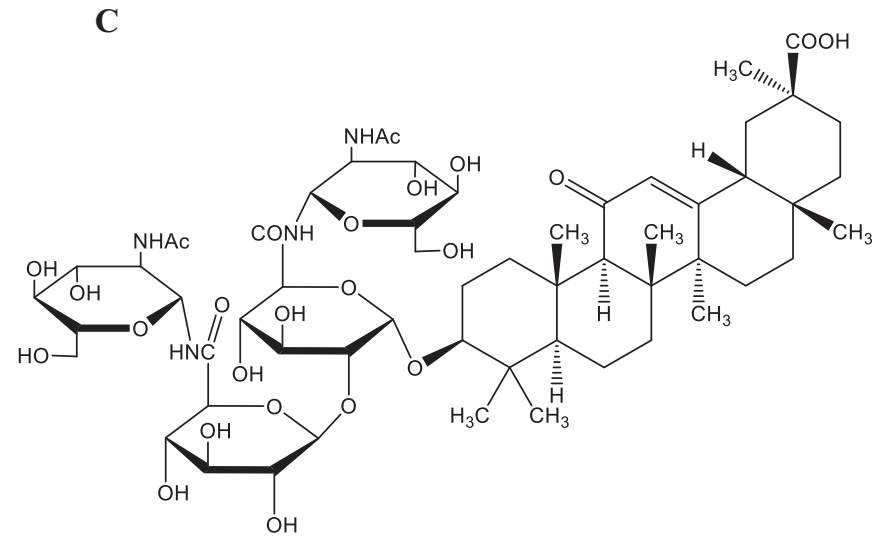

Table 2 Binding energies of glycyrrhizic acid and glycyrhhizin with SARS-CoV-2 target proteins

\begin{tabular}{lll}
\hline Target/PDB Code & Glycyrrhizic Acid [55] & Glycyrrhizin [56] \\
\hline $\mathrm{M}^{\text {Pro / 7K3T }}$ & -8.7 & -8.1 \\
$\mathrm{PL}^{\text {Pro / 6W9C }}$ & -8.2 & -7.9 \\
$\mathrm{RdRp} / 7 \mathrm{BV} 2$ & -9.9 & - \\
$\mathrm{N} / 6 \mathrm{YVO}$ & - & -7.9 \\
$\mathrm{~S} / 6 \mathrm{VXX}$ & -9.3 & - \\
Human ACE2 / 7A98 & -9.5 & -
\end{tabular}

$\overline{\mathrm{M}^{\text {Pro }} \text {-Main Protease (3CL }}{ }^{\text {Pro }}$, Chymotripsin-like Protease); $\mathrm{PL}^{\text {Pro }}$ Papain-like Protease; RdRp-RNA-dependent RNA polymerase; $\mathrm{N}$-Nucleocapsid protein; S-Spike protein; Human ACE2-Angiotensin Converting Enzyme 2 (human host cell surface)

The flavonoids apigenin chrysin, galangin, hesperetin, kaempferol, luteolin, naringenin and quercetin (Fig. 2), the flavonoid glycoside rutin (Fig. 3A), the isoflavone phytoestrogen daidzein (Fig. 3B), neobavaisoflavone (Fig. 3C) and the catechins from dietary sources, such as green tea (Fig. 4), are flavonoids or closely related compounds found in a variety of fruits and vegetables. These compounds diminish a number of inflammatory processes related to cyclooxygenase-2 (COX-2) and iNOS activity, NFkB, Activator Protein-1 (AP-1) and mitogen activated protein kinase (MAPK) activities [57]. Such activities reduce the synthesis of inflammatory markers such as IL-1 $\beta, \mathrm{IL}-6, \mathrm{IFN}-\gamma$ and TNF- $\alpha$, whose elevated concentrations are noted in patients experiencing severe symptoms of SARS-CoV-2 infection [57]. Non-flavonoid anti-oxidants and anti-inflammatories found in fruits, vegetables, grains and cereals such as caffeic, ferulic, $p$ coumaric, syringic and vanillic acids, eriodictyol, polydatin and resveratrol (Fig. 5), also play roles in inhibiting lipid peroxidation and free radical scavenging. These activities lead to the decreased synthesis and effects of the aforementioned markers of inflammation in SARS-CoV-2. In fact, eriodictyol, one of its glycosides, and polydatin, bind ACE2 and inhibit SARS-CoV-2 main protease $\left(\mathrm{M}^{\mathrm{Pro}}\right)$ [57].

A flavonoid enriched extract of the skullcap root, $\mathrm{Scu}$ tellaria baicalensis, rich in the flavonoids, scutellarein, baicalein and its glycoside, baicalin, as well as other flavonoids decreased the production of inflammatory cytokines TNF- $\alpha$, IL-6, monocyte chemotactic factor-1 (MCP1) and nitric oxide in mouse lung tissues exposed to influenza A virus, while increasing the synthesis of protective cytokines IFN- $\gamma$ and IL-10 [61]. In examining a TCM formula rich in flavonoids (baicalein, isorhamnetin, kaempferol, luteolin, naringenin, quercetin and wogonin), extracts rich in these compounds suppressed IL-6 production in macrophages in vitro, and downregulated TNF- $\alpha$ and NFKB 
Fig. 2 Flavonoids

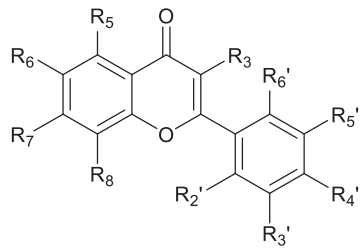

\begin{tabular}{|c|c|c|c|c|c|c|c|c|c|c|}
\hline & $\mathrm{R}_{3}$ & $\mathrm{R}_{5}$ & $\mathrm{R}_{6}$ & $\mathrm{R}_{7}$ & $\mathrm{R}_{8}$ & $\mathrm{R}_{2}{ }^{\prime}$ & $\mathrm{R}_{3}{ }^{\prime}$ & $\mathrm{R}_{4}^{\prime}$ & $\mathrm{R}_{5}{ }^{\prime}$ & $\mathrm{R}_{6}{ }^{\prime}$ \\
\hline Apigenin & $\mathrm{H}$ & $\mathrm{OH}$ & $\mathrm{H}$ & $\mathrm{OH}$ & $\mathrm{H}$ & $\mathrm{H}$ & $\mathrm{H}$ & $\mathrm{OH}$ & $\mathrm{H}$ & $\mathrm{H}$ \\
\hline Baicalein & $\mathrm{H}$ & $\mathrm{OH}$ & $\mathrm{OH}$ & $\mathrm{OH}$ & $\mathrm{H}$ & $\mathrm{H}$ & $\mathrm{H}$ & $\mathrm{H}$ & $\mathrm{H}$ & $\mathrm{H}$ \\
\hline Caflanone & $\mathrm{H}$ & $\mathrm{OH}$ & $\mathrm{H}$ & $\mathrm{OH}$ & $\mathrm{C}_{5} \mathrm{H}_{9}$ & $\mathrm{H}$ & $\mathrm{OCH}_{3}$ & $\mathrm{OH}$ & $\mathrm{H}$ & $\mathrm{H}$ \\
\hline Chrysin & $\mathrm{H}$ & $\mathrm{OH}$ & $\mathrm{H}$ & $\mathrm{OH}$ & $\mathrm{H}$ & $\mathrm{H}$ & $\mathrm{H}$ & $\mathrm{H}$ & $\mathrm{H}$ & $\mathrm{H}$ \\
\hline Galangin & $\mathrm{OH}$ & $\mathrm{OH}$ & $\mathrm{H}$ & $\mathrm{OH}$ & $\mathrm{H}$ & $\mathrm{H}$ & $\mathrm{H}$ & $\mathrm{H}$ & $\mathrm{H}$ & $\mathrm{H}$ \\
\hline Herbacetin & $\mathrm{OH}$ & $\mathrm{OH}$ & $\mathrm{H}$ & $\mathrm{OH}$ & $\mathrm{OH}$ & $\mathrm{H}$ & $\mathrm{H}$ & $\mathrm{OH}$ & $\mathrm{H}$ & $\mathrm{H}$ \\
\hline Hesperetin (2,3 dihydro) & $\mathrm{H}, \mathrm{H}$ & $\mathrm{OH}$ & $\mathrm{H}$ & $\mathrm{OH}$ & $\mathrm{H}$ & $\mathrm{H}$ & $\mathrm{OH}$ & $\mathrm{OCH}_{3}$ & $\mathrm{H}$ & $\mathrm{H}$ \\
\hline Isorhamentin & $\mathrm{OH}$ & $\mathrm{OH}$ & $\mathrm{H}$ & $\mathrm{OH}$ & $\mathrm{H}$ & $\mathrm{H}$ & $\mathrm{OCH}_{3}$ & $\mathrm{OH}$ & $\mathrm{H}$ & $\mathrm{H}$ \\
\hline Kaempferol & $\mathrm{OH}$ & $\mathrm{OH}$ & $\mathrm{H}$ & $\mathrm{OH}$ & $\mathrm{H}$ & $\mathrm{H}$ & $\mathrm{H}$ & $\mathrm{OH}$ & $\mathrm{H}$ & $\mathrm{H}$ \\
\hline Luteolin & $\mathrm{H}$ & $\mathrm{OH}$ & $\mathrm{H}$ & $\mathrm{OH}$ & $\mathrm{H}$ & $\mathrm{H}$ & $\mathrm{OH}$ & $\mathrm{OH}$ & $\mathrm{H}$ & $\mathrm{H}$ \\
\hline Morin & $\mathrm{OH}$ & $\mathrm{OH}$ & $\mathrm{H}$ & $\mathrm{OH}$ & $\mathrm{H}$ & $\mathrm{OH}$ & $\mathrm{H}$ & $\mathrm{OH}$ & $\mathrm{H}$ & $\mathrm{H}$ \\
\hline Myricetin & $\mathrm{OH}$ & $\mathrm{OH}$ & $\mathrm{H}$ & $\mathrm{OH}$ & $\mathrm{H}$ & $\mathrm{H}$ & $\mathrm{OH}$ & $\mathrm{OH}$ & $\mathrm{OH}$ & $\mathrm{H}$ \\
\hline Naringenin (2,3 dihydro) & $\mathrm{H}, \mathrm{H}$ & $\mathrm{OH}$ & $\mathrm{H}$ & $\mathrm{OH}$ & $\mathrm{H}$ & $\mathrm{H}$ & $\mathrm{H}$ & $\mathrm{OH}$ & $\mathrm{H}$ & $\mathrm{H}$ \\
\hline Nobiletin & $\mathrm{H}$ & $\mathrm{OCH}_{3}$ & $\mathrm{OCH}_{3}$ & $\mathrm{OCH}_{3}$ & $\mathrm{OCH}_{3}$ & $\mathrm{H}$ & $\mathrm{OCH}_{3}$ & $\mathrm{OCH}_{3}$ & $\mathrm{H}$ & $\mathrm{H}$ \\
\hline Quercetin & $\mathrm{OH}$ & $\mathrm{OH}$ & $\mathrm{H}$ & $\mathrm{OH}$ & $\mathrm{H}$ & $\mathrm{H}$ & $\mathrm{OH}$ & $\mathrm{OH}$ & $\mathrm{H}$ & $\mathrm{H}$ \\
\hline Rhamentin & $\mathrm{OH}$ & $\mathrm{OH}$ & $\mathrm{H}$ & $\mathrm{OCH}_{3}$ & $\mathrm{H}$ & $\mathrm{H}$ & $\mathrm{OH}$ & $\mathrm{OH}$ & $\mathrm{H}$ & $\mathrm{H}$ \\
\hline Scutellarein & $\mathrm{H}$ & $\mathrm{OH}$ & $\mathrm{OH}$ & $\mathrm{OH}$ & $\mathrm{H}$ & $\mathrm{H}$ & $\mathrm{H}$ & $\mathrm{OH}$ & $\mathrm{H}$ & $\mathrm{H}$ \\
\hline Tangeretin & $\mathrm{H}$ & $\mathrm{OCH}_{3}$ & $\mathrm{OCH}_{3}$ & $\mathrm{OCH}_{3}$ & $\mathrm{OCH}_{3}$ & $\mathrm{H}$ & $\mathrm{H}$ & $\mathrm{OCH}_{3}$ & $\mathrm{H}$ & $\mathrm{H}$ \\
\hline Wogonin & $\mathrm{H}$ & $\mathrm{OH}$ & $\mathrm{H}$ & $\mathrm{OH}$ & $\mathrm{OCH}_{3}$ & $\mathrm{H}$ & $\mathrm{H}$ & $\mathrm{H}$ & $\mathrm{H}$ & $\mathrm{H}$ \\
\hline
\end{tabular}
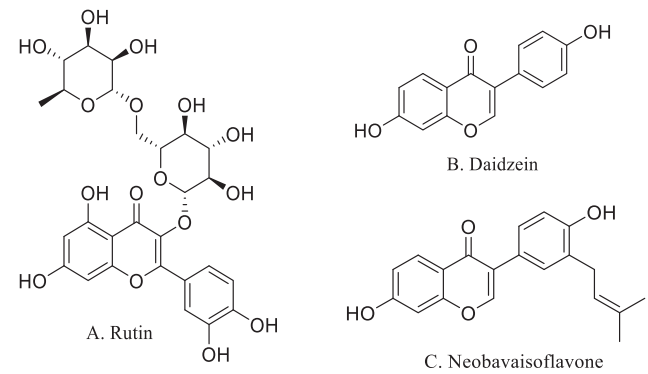

Fig. 3 Flavonoid-related compounds. A rutin. B daidzein. C neobavaisoflavone

signaling in addition to attenuating a host of other inflammatory signaling pathways [62].

Flavonoids interact with a number of viral targets including those involved with entry into host cells, genome transcription, post-translational modification and others related to viral viability. Solnier and Fladerer [59] summarized the results of flavonoids and related compounds binding to $\mathrm{CL}^{\text {Pro }}\left(\mathrm{M}^{\mathrm{Pro}}\right)$ and $\mathrm{PL}^{\text {Pro }}$ of SARS-CoV and MERS-CoV in FRET assays. With the lowest $\mathrm{IC}_{50}$ values being the best, flavonoids bound SARS-CoV CL ${ }^{\text {Pro }}$ with $\mathrm{IC}_{50}$ value ranges of $8.3-381 \mu \mathrm{M}$ and MERS CoV CL ${ }^{\text {Pro }}$ with $\mathrm{IC}_{50}$ value ranges of $34.7-125.7 \mathrm{mM}$. Chalcones, dimeric structures of flavonoids, bound SARS-CoV CL ${ }^{\text {Pro }}$ with $\mathrm{IC}_{50}$ value ranges of $11.4-202.7 \mu \mathrm{M}$ and MERS CoV $\mathrm{CL}^{\text {Pro }}$ with $\mathrm{IC}_{50}$ value ranges of $27.9-193.7 \mathrm{mM}$. Flavonoids bound SARS-CoV PL Pro with $\mathrm{IC}_{50}$ value ranges of
3.7-66.2 $\mu \mathrm{M}$ and MERS-CoV PL Pro with $\mathrm{IC}_{50}$ value ranges of 48.8-206.6 mM. Chalcones bound SARS-CoV PL Pro with $\mathrm{IC}_{50}$ value ranges of $1.2-46.4 \mu \mathrm{M}$ and MERS-CoV $\mathrm{PL}^{\text {Pro }}$ with $\mathrm{IC}_{50}$ value ranges of $42.1-171.6 \mathrm{mM}$ (Table 3) [59]. Binding to $\mathrm{CL}^{\text {Pro }}$ is somewhat more erratic for flavonoids and chalcones, but binding to $\mathrm{PL}^{\text {Pro }}$ is less erratic and somewhat more potent. From this data, it may be more beneficial to base the development of $\mathrm{PL}^{\text {Pro }}$ inhibitors on chalcones, rather than flavonoids and to use flavonoids as the basis for the development of either $\mathrm{CL}^{\text {Pro }}$ or $\mathrm{PL}^{\text {Pro }}$ inhibitors.

Goyal and colleagues [63] completed molecular docking studies of SARS-CoV-2 RdRp with various flavonoids and triterpenes and compared them with uridine and thymidine triphosphates (UTP, TTP) and remdesivir, an effective $\mathrm{RdRp}$ inhibitor used in the treatment of COVID-19, as controls. Docking scores for the twenty compounds tested were all within $4 \mathrm{kcal} / \mathrm{mol}$ of the controls, and their binding free energies were on par with controls or at least within $80 \mathrm{kcal} / \mathrm{mol}$ of controls. The controls and the compounds tested appear to interact with the same amino acid residues in RdRp, namely serine, lysine, arginine, aspartate and isoleucine (Table 4). Molecular modeling demonstrates weak intermolecular interactions occurring between hydroxyl groups, ether oxygens and carbonyl oxygen atoms of the flavonoid and triterpene structures with amino acid residues of $\operatorname{RdRp}$ [63]. With respect to RdRp and ACE2, 
<smiles>Oc1cc(O)c2c(c1)O[C@H](c1ccc(O)c(O)c1)[C@@H](O)C2c1ccc(O)c(O)c1</smiles><smiles>Oc1cc(O)c2c(c1)O[C@H](c1ccc(O)c(O)c1)[C@H](O)C[C@@H]2c1ccc(O)c(O)c1</smiles><smiles>O=C(O[C@H]1Cc2c(O)cc(O)cc2O[C@H]1c1ccc(O)c(O)c1)c1cc(O)c(O)c(O)c1</smiles>

(+)-epicatechin-3-gallate "(+)-ECG"<smiles>O=C(O[C@H]1Cc2c(O)cc(O)cc2O[C@H]1c1ccc(O)c(O)c1)c1cc(O)c(O)c(O)c1</smiles>

(-)-epicatechin-3-gallate "(-)-ECG"<smiles>Oc1cc(O)c2c(c1)O[C@H](c1cc(O)c(O)c(O)c1)[C@H](O)C2</smiles><smiles>Oc1cc(O)c2c(c1)O[C@H](c1cc(O)c(O)c(O)c1)[C@H](O)C2</smiles><smiles>O=C(O[C@H]1Cc2c(O)cc(O)cc2OC1c1cc(O)c(O)c(O)c1)c1cc(O)c(O)c(O)c1</smiles>

(-)-epigallocatechin-3-gallate "EGCG"

Fig. 4 Catechins from green tea
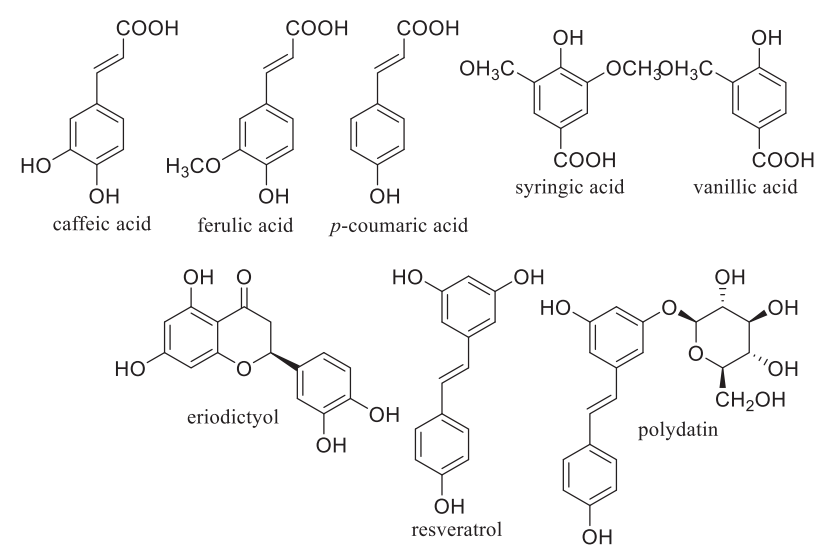

Fig. 5 Non-flavonoid anti-oxidants and anti-inflammatories from the diet
Table $3 \mathrm{IC}_{50}$ value ranges of flavonoids and chalcones with SARS$\mathrm{CoV}$ and MERS-CoV CL ${ }^{\text {Pro }}$ and $\mathrm{PL}^{\text {Pro }}$ [59]

\begin{tabular}{|c|c|c|c|c|}
\hline & \multicolumn{4}{|c|}{$\mathrm{IC}_{50}$ Value Ranges $(\mu \mathrm{M})$} \\
\hline & $\begin{array}{l}\text { SARS-CoV } \\
\text { CL }^{\text {Pro }}\end{array}$ & $\begin{array}{l}\text { SARS- } \\
\text { CoV PL Pro }\end{array}$ & $\begin{array}{l}\text { MERS-CoV } \\
\text { CL Pro }^{\text {Pen }}\end{array}$ & $\begin{array}{l}\text { MERS-CoV } \\
\text { PL }^{\text {Pro }}\end{array}$ \\
\hline Flavonoids & $8.3-381$ & $3.7-66.2$ & $34.7-125.7$ & $48.8-206.6$ \\
\hline Chalcones & $11.4-202.7$ & $1.2-46.4$ & $27.9-193.7$ & $42.1-171.6$ \\
\hline
\end{tabular}

Table 4 Binding interactions common to flavonoids and glycyrrhizic acid in RdRp, and flavonoids and glycyrrhizinic acid in ACE2 [55, 63]

\begin{tabular}{ll}
\hline RdRp (PDB Codes 6M71 and & ACE2 (PDB Codes 6M17 and \\
7BV2) [41, 89] & 2AJF) [90, 91]
\end{tabular}

Glycyrrhizic Acid [55] Flavonoid ${ }^{a}$ Glycyrrhzinic Acid [55] Flavonoid

Glycoside $^{\mathrm{b}}$

[63]

\begin{tabular}{|c|c|c|}
\hline $\operatorname{Arg}^{555}, \operatorname{Ser}^{682}$ & Apigenin $^{\mathrm{a}}$ & $\mathrm{Ala}^{348}$ \\
\hline $\operatorname{Arg}^{555}, \mathrm{Ile}^{548}$ & $\begin{array}{l}\text { Apigenin-7- } \\
O \text {-glucoside }\end{array}$ & $\mathrm{Ala}^{348}, \mathrm{Arg}^{393}, \mathrm{Asn}^{394}$ \\
\hline $\operatorname{Arg}^{555}$ & Galangin $^{\mathrm{a}}$ & $\mathrm{Asn}^{394}, \mathrm{Asp}^{350}, \mathrm{Arg}^{393}$ \\
\hline $\operatorname{Arg}^{555}, \operatorname{Ser}^{682}$ & Hesperetin $^{\mathrm{a}}$ & $\mathrm{Ala}^{348}, \mathrm{Arg}^{393}, \mathrm{Asn}^{394}$ \\
\hline Lys $^{545}, \mathrm{Ile}^{548}$ & Hesperidin $^{\mathrm{b}}$ & $\mathrm{Tyr}^{385}, \mathrm{Ala}^{348}, \mathrm{Arg}^{393}$ \\
\hline $\operatorname{Arg}^{555}$ & Kaempferol $^{\mathrm{a}}$ & $\mathrm{Asn}^{394}$ \\
\hline $\mathrm{Ile}^{548}$ & Luteolin $^{\mathrm{a}}$ & $\mathrm{Ala}^{348}$ \\
\hline $\mathrm{Ile}^{548}$ & $\begin{array}{l}\text { Luteolin-7- } \\
O \text {-glucoside }\end{array}$ & $\mathrm{Glu}^{402}$ \\
\hline $\operatorname{Ser}^{682}$ & Naringenin $^{\mathrm{a}}$ & - \\
\hline $\operatorname{Ser}^{549}, \operatorname{Asp}^{623}$ & Naringin $^{\mathrm{b}}$ & $\mathrm{Ala}^{348}, \mathrm{Arg}^{393}$ \\
\hline $\operatorname{Ser}^{682}$ & Quercetin $^{\mathrm{a}}$ & $\mathrm{Ala}^{348}$ \\
\hline $\mathrm{Ile}^{548}, \mathrm{Asp}^{623}, \mathrm{Lys}^{551}, \mathrm{Arg}^{555}$ & Rutin $^{\mathrm{a}}$ & $\mathrm{Asn}^{394}$ \\
\hline
\end{tabular}

${ }^{\mathrm{a}}$ Flavonoid

${ }^{\mathrm{b}}$ Flavonoid glycoside

Goyal and colleagues found a number of binding interactions between various flavonoids/flavonoid glycosides and amino acid residues that share commonality with residues to which glycyrrhizic acid and glycyrrhizinic acid bind as noted by Vardhan and Sahoo (Table 4) [55, 63]. While molecular docking studies are not a guarantee that such compounds would interact with the target in vivo, there is some likelihood that they can, and by examining these commonalities in binding interactions these molecules such as these could serve as useful templates for antiviral drug development.

Molecular docking studies of flavonoid and triterpene binding to ACE2 gave docking scores within $3 \mathrm{kcal} / \mathrm{mol}$ of control and binding free energy values within $30 \mathrm{kcal} / \mathrm{mol}$ of control. Compounds tested bound key alanine, aspartate and arginine residues in binding models. These residues were among those bound by the known ACE2 inhibitor, 
Fig. 6 Selected constituents of Cannabis sativa $\mathrm{L}$
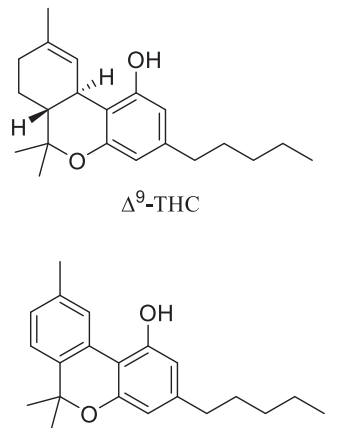

CBN
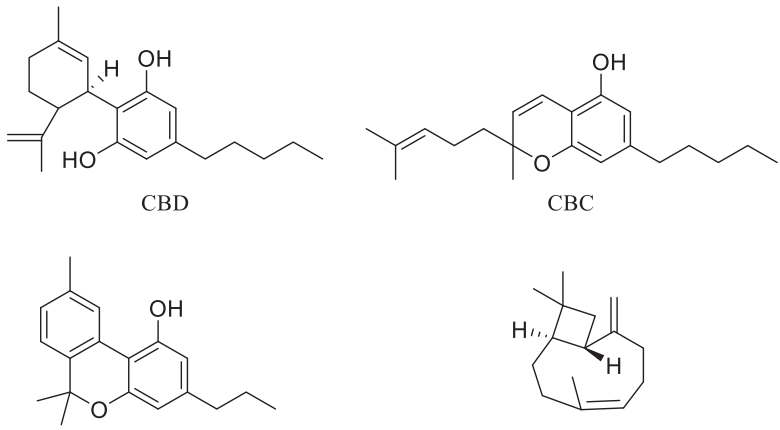

CBV

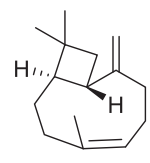

$\mathrm{BCP}$
GL1001 $\left(\mathrm{Ala}^{348}, \operatorname{Trp}^{349}, \mathrm{Asp}^{350}, \mathrm{Asp}^{382}\right.$ and $\left.\mathrm{Arg}^{393}\right)$. Again, models reveal weak intermolecular interactions occurring between hydroxyl groups, ether oxygens and carbonyl oxygen atoms of the flavonoid and triterpene structures with amino acid residues of ACE2 [63]. The structures of such flavonoids and triterpenes could be optimized to serve as potential leads for drug development.

$\mathrm{Su}$ and colleagues studied the effects of a Chinese patent medicine, whose name is Shuanghuanglian, on SARS-CoV-2 in vitro [64]. Shuanghuanglian is a multicomponent composition rich in the flavonoid, baicalein, found in Scutellaria baicalensis, and a number of other related compounds from Forsythia suspensa. As determined by molecular modeling studies, baicalein binds to a core region of the SARS-CoV-2 $\mathrm{CL}^{\mathrm{Pro}}\left(\mathrm{M}^{\mathrm{Pro}}\right)$, by hydrogen bond interactions with leucine and glycine, glutamate and serine and glycine with the assistance of water, and by hydrophobic and/or pi stacking interactions with glutamine, arginine, methionine, cysteine and histidine residues. Baicalein inhibits SARS-CoV-2 $\mathrm{M}^{\text {Pro }}$ with an $\mathrm{IC}_{50}$ of $\sim 0.94 \mu \mathrm{M}$, as well. Baicalein's glycoside, baicalin, also inhibited SARS-CoV-2 $\mathrm{M}^{\text {Pro }}$, but inhibition was nearly $10-$ fold weaker at $\sim 6.41 \mu \mathrm{M}$. Interestingly, seven other compounds from Shuanghuanglian, namely the catecholic glycosides forsythoside A, B, E, H, I, isoforsythoside and scutellarein, a flavonoid closely related to baicalein, also inhibited SARS-CoV-2 $\mathrm{M}^{\text {Pro }}$, albeit with potency less than that of baicalein, with $\mathrm{IC}_{50}$ values ranging from 2.88 to $10.17 \mu \mathrm{M}$. These compounds could also serve as initial leads for anti-SARS-CoV-2 drug development.

A number of other compounds whose structures resemble the scaffolds of natural products have been found to inhibit SARS-CoV-2 $\mathrm{M}^{\mathrm{Pro}}$ in the COVID Moonshot project. The COVID Moonshot project is a crowdsourced consortium of scientists from around the world using molecular modeling and crystallographic techniques, high-throughput synthesis, solubility and screening methodology, and artificial intelligence in the effort to find lead compounds active against SARS-CoV-2 $\mathrm{M}^{\text {Pro }}$ [65].

Not only do flavonoids and triterpenes display potential to bind ACE2, the cell surface receptor for SARS-CoV and
SARS-CoV-2, flavonoids and their glycosides, gingerols and cannabinoids all demonstrate binding to the main protease $\mathrm{M}^{\mathrm{Pro}}$ and $\mathrm{S}$ protein of SARS-CoV-2. Recall that the $\mathrm{S}$ protein of the virus interacts with ACE2 on the cell surface, whereby viral entry to the cell is gained. Binding free energies of flavonoids and their glycosides, gingerols and cannabinoids are low and comparable. The best binding to $\mathrm{S}$ protein was accomplished by epigallocatechin gallate, a well-known constituent of green tea, the flavonoid glycosides hesperidin, rhoifolin, pectolinarin and the cannabinoids, cannabidiol and $\Delta^{9}$-THC [66]. Thus, all of these compounds could serve as useful scaffolds for drug design and lead development of anti-SARS-CoV-2 drugs.

\section{Cannabis}

Cannabis sativa $\mathrm{L}$. has been used as a phytomedicinal substance for centuries, dating back to the Han Dynasty in China [67]. Of more than 550 compounds identified from C. sativa, there are at least 113 cannabinoids, 140 terpenes and at least 23 flavonoids [68, 69]. Cannabinoids derived from Cannabis sativa $\mathrm{L}$. bind $\mathrm{CB} 1$ and $\mathrm{CB} 2$ receptors in the endocannabinoid system [70]. While the psychoactive cannabinoid, $\Delta^{9}$-THC (Fig. 6) is known to bind CB1 receptors, promote relaxation of the vasculature and inhibit IL-1 $\beta$ production [71-73], cannabidiol (CBD, Fig. 6), cannabichromene (CBC, Fig. 6) and cannabinol (CBN, Fig. 6) bind $\mathrm{CB} 2$ receptors with resulting decreases in the proinflammatory cytokines $[73,74]$. CBD has been shown to stimulate peroxisome-proliferator activated receptors alpha and gamma (PPAR- $\alpha$ and PPAR- $\gamma$ ) to attenuate the pathways leading to proinflammatory cytokine release [70, 73, 75, 76]. Through their actions at inflammasomes and the transient cation receptor potential channels (TRPs) these non-psychoactive cannabinoids depress the NFKB signaling pathway, decreasing the release of IL- 6 , IL- $1 \beta$, IFN- $\gamma$ and TNF- $\alpha$ in animal and in vitro models [77-79]. Thus, the interest in cannabinoids to diminish the effects of the cytokine storm as a serious manifestation of SARS-CoV-2 infection is pronounced, of late. 
In molecular docking studies of cannabinoids and their binding to ACE2, TMPSS2, IL-6 and the histone chaperone NRP1, CBD and cannabivarin (CBV, Fig. 6) demonstrated significant binding affinity with binding free energies between -8.2 and $-8.9 \mathrm{kcal} / \mathrm{mol}$ [80]. Binding of the cannabinoid with the these target proteins results in downregulation of corresponding activity and an implied competition between binding of cannabinoids and the endogenous ligand [80].

Not only do cannabinoids diminish the release of proinflammatory cytokines, extracts high in CBD concentration also downregulate expression of the ACE2 receptor and TMPSS2 [81-83]. However, the effects on ACE2 and TMPSS2 expression cannot be related solely to CBD concentration [75, 82]. Extracts of cannabis contain bioactive terpenes as well. The relatively higher biological activity of cannabis extracts containing a combination of cannabinoids and terpenes may be explained by the entourage effect, where a complex mixture of compounds in a plant extract demonstrates greater biological activity than a single constituent alone [73, 82].

Terpenes are noted for the aromatic character and flavor they impart to cannabis plants [67]. Mentioned previously, terpenes found in cannabis extracts may account for an entourage effect. $\beta$-Caryophyllene (BCP, Fig. 6) is a terpene found in cannabis as well as a number of other plant species, and is a full agonist of CB2 receptors [84]. BCP also activates peroxisome-proliferator activated receptors alpha and gamma (PPAR- $\alpha$ and PPAR- $\gamma$ ) leading to attenuation of the pathways causing proinflammatory cytokine release [84]. Interestingly, BCP also binds SARS-CoV-2 $\mathrm{M}^{\mathrm{Pro}}$ with a binding free energy of $-7.2 \mathrm{kcal} / \mathrm{mol}$, which is comparable to that of glycyrrhizin, $-8.1 \mathrm{kcal} / \mathrm{mol}$ [69].

As stated, at least 23 flavonoids have been isolated from cannabis. Caflanone, a.k.a. isocannflavin B (Fig. 2), a flavonoid derived from cannabis, was shown to bind the metalloproteinase domain of ACE2 [85]. Other flavonoids and chloroquine also bind the metalloproteinase domain, however caflanone's binding free energy of $-7.9 \mathrm{kcal} / \mathrm{mol}$ is lower than that of chloroquine $(-4.1$ or $-4.7 \mathrm{kcal} / \mathrm{mol})$, implying better binding in the ACE2 metalloproteinase domain. Other flavonoids discussed above, such as myricetin and hesperitin, bind the ACE2 metalloproteinase domain with free energies of $-8.9 \mathrm{kcal} / \mathrm{mol}$ and $-9.1 \mathrm{kcal} /$ mol respectively, comparable to that of caflanone [85].

Given the effects of cannabis constituents on systems involved in the serious complications of COVID-19 and the wide availability of cannabis in the community today, it is no wonder that there is so much interest in cannabis as a potential therapy for the severe complications of SARS-CoV-2 infection. However, the effects of smoking and/or vaping cannabis can be deleterious to the lungs, many unsubstantiated claims have been made in the media and there has not been adequate clinical research to support the use of cannabis as a treatment or preventive therapy for COVID-19 [86, 87].

\section{Conclusion}

While the flavonoids and their related compounds, and other naturally occurring anti-oxidants and antiinflammatories discussed display these beneficial properties, it is important to realize their bioavailability from the diet is limited. When ingested these compounds are subject to hepatic first-pass metabolic transformations and conjugation reactions that decrease their absorption and promote their elimination from the body. Dabeek and Marra have reviewed the bioavailability of the flavonoids, quercetin and kaempferol. In their work they detailed a number of food sources for these flavonoids and their glycosides, and discussed the kinetics behind their absorption, metabolism and excretion [88]. Complicating matters is the notion that extracts of natural products contain constituents that often act in synergy to illicit their effects, and that when individual constituents are purified their activity diminishes or disappears. With this in mind, a diet consistently rich in fruits, vegetables, grains and cereals affords the best chances for these bioactive compounds to be present in order to have and maintain their effects on viral entry and replication, and the inflammatory processes related to the consequences of moderate to severe infection. As claims are concerned, we must be reminded that US Federal Law does not permit claims for the treatment, cure or diagnosis of diseases such as COVID-19. Regardless, at this point it would be desirable to conduct well-designed clinical trials with specific doses of standardized products in order to determine the actual utility of natural compounds in the treatment of COVID-19.

\section{Compliance with ethical standards}

Conflict of interest The authors declare no competing interests.

Publisher's note Springer Nature remains neutral with regard to jurisdictional claims in published maps and institutional affiliations.

\section{References}

1. Organization WH. WHO Coronavirus (COVID-19) Dashboard. World Health Organization. 2021. https://covid19.who.int/?a dgroupsurvey $=\% 7$ badgroupsurvey $\% 7 \mathrm{~d} \&$ gclid $=$ EAIa IQobChMIoejY_42S7wIVHj6tBh3IggpTEAAYASABEgJ8v_D_ BwE. Accessed Aug 242021.

2. Chen AT, Altschuler K, Zhan SH, Chan YA, Deverman BE. COVID-19 CG enables SARS-CoV-2 mutation and lineage tracking by locations and dates of interest. Elife. 2021;10. https:// doi.org/10.7554/eLife.63409. 
3. To KK, Hung IF, Ip JD, Chu AW, Chan WM, Tam AR, et al. COVID-19 re-infection by a phylogenetically distinct SARScoronavirus-2 strain confirmed by whole genome sequencing. Clin Infect Dis. 2020. https://doi.org/10.1093/cid/ciaa1275.

4. Karki R, Sharma BR, Tuladhar S, Williams EP, Zalduondo L, Samir P. et al. Synergism of TNF- $\alpha$ and IFN- $\gamma$ triggers inflammatory cell death, tissue damage, and mortality in SARS-CoV-2 infection and cytokine shock syndromes. Cell. 2021;184:149-68. e17. https://doi.org/10.1016/j.cell.2020.11.025.

5. Platanitis E, Decker T. Regulatory Networks Involving STATs, IRFs, and NFKB in Inflammation. Front Immunol. 2018;9:2542. https://doi.org/10.3389/fimmu.2018.02542.

6. Xu J, Zhao S, Teng T, Abdalla AE, Zhu W, Xie L, et al. Systematic comparison of two animal-to-human transmitted human coronaviruses: SARS-CoV-2 and SARS-CoV. Viruses. 2020;12. https://doi.org/10.3390/v12020244.

7. Grifoni A, Sidney J, Zhang Y, Scheuermann RH, Peters B, Sette A. A sequence homology and bioinformatic approach can predict candidate targets for immune responses to SARS-CoV-2. Cell Host Microbe. 2020;27:671-80.e2. https://doi.org/10.1016/j. chom.2020.03.002.

8. Zaki AM, van Boheemen S, Bestebroer TM, Osterhaus AD, Fouchier RA. Isolation of a novel coronavirus from a man with pneumonia in Saudi Arabia. N. Engl J Med. 2012;367:1814-20. https://doi.org/10.1056/NEJMoa1211721.

9. Liu Z, Xiao X, Wei X, Li J, Yang J, Tan H. et al. Composition and divergence of coronavirus spike proteins and host ACE2 receptors predict potential intermediate hosts of SARS-CoV-2. J Med Virol. 2020;92:595-601. https://doi.org/10.1002/jmv.25726.

10. Malik YS, Sircar S, Bhat S, Sharun K, Dhama K, Dadar M. et al. Emerging novel coronavirus (2019-nCoV)-current scenario, evolutionary perspective based on genome analysis and recent developments. Vet Q. 2020;40:68-76. https://doi.org/10.1080/ 01652176.2020.1727993.

11. Samudrala PK, Kumar P, Choudhary K, Thakur N, Wadekar GS, Dayaramani R. et al. Virology, pathogenesis, diagnosis and in-line treatment of COVID-19. Eur J Pharm. 2020;883:173375. https:// doi.org/10.1016/j.ejphar.2020.173375.

12. Khare P, Sahu U, Pandey SC, Samant M. Current approaches for target-specific drug discovery using natural compounds against SARS-CoV-2 infection. Virus Res. 2020;290:198169. https://doi. org/10.1016/j.virusres.2020.198169.

13. Tleyjeh IM, Kashour Z, Damlaj M, Riaz M, Tlayjeh H, Altannir M. et al. Efficacy and safety of tocilizumab in COVID-19 patients: a living systematic review and meta-analysis. Clin Microbiol Infect. 2021;27:215-27. https://doi.org/10.1016/j.cmi.2020.10. 036.

14. Fuzimoto $\mathrm{AD}$, Isidoro $\mathrm{C}$. The antiviral and coronavirus-host protein pathways inhibiting properties of herbs and natural compounds - Additional weapons in the fight against the COVID-19 pandemic?. J Tradit Complement Med. 2020;10:405-19. https:// doi.org/10.1016/j.jtcme.2020.05.003.

15. Du HZ, Hou XY, Miao YH, Huang BS, Liu DH. Traditional Chinese Medicine: an effective treatment for 2019 novel coronavirus pneumonia (NCP). Chin J Nat Med. 2020;18:206-10. https://doi.org/10.1016/s1875-5364(20)30022-4.

16. Ren JL, Zhang AH, Wang XJ. Traditional Chinese medicine for COVID-19 treatment. Pharm Res. 2020;155:104743. https://doi. org/10.1016/j.phrs.2020.104743.

17. Liu CX. Pay attention to situation of SARS-CoV-2 and TCM advantages in treatment of novel coronavirus infection. Chin Herb Med. 2020;12:97-103. https://doi.org/10.1016/j.chmed.2020.03. 004 .

18. Zhang L, Yu J, Zhou Y, Shen M, Sun L. Becoming a Faithful Defender: Traditional Chinese Medicine against Coronavirus
Disease 2019 (COVID-19). Am J Chin Med. 2020;48:763-77. https://doi.org/10.1142/s0192415x2050038x.

19. Zhong LLD, Lam WC, Yang W, Chan KW, Sze SCW, Miao J. et al. Potential Targets for Treatment of Coronavirus Disease 2019 (COVID-19): A Review of Qing-Fei-Pai-Du-Tang and Its Major Herbs. Am J Chin Med. 2020;48:1051-71. https://doi.org/10. 1142/s0192415x20500512.

20. Huang ST, Lai HC, Lin YC, Huang WT, Hung HH, Ou SC, et al. Principles and treatment strategies for the use of Chinese herbal medicine in patients at different stages of coronavirus infection. Am J Cancer Res. 2020;10:2010-31.

21. Pang W, Liu Z, Li N, Li Y, Yang F, Pang B. et al. Chinese medical drugs for coronavirus disease 2019: a systematic review and meta-analysis. Integr Med Res. 2020;9:100477. https://doi. org/10.1016/j.imr.2020.100477.

22. Fan TT, Cheng BL, Fang XM, Chen YC, Su F. Application of Chinese Medicine in the management of critical conditions: a review on Sepsis. Am J Chin Med. 2020;48:1315-30. https://doi. org/10.1142/s0192415x20500640.

23. Zhang XR, Li TN, Ren YY, Zeng YJ, Lv HY, Wang J. et al. The important role of volatile components from a Traditional Chinese Medicine Dayuan-Yin Against the COVID-19 Pandemic. Front Pharm. 2020;11:583651. https://doi.org/10.3389/fphar.2020. 583651.

24. Zhang Y, Li Y, Wang X, Qu R, Li J, Li T. et al. Herbal plants coordinate COVID-19 in multiple dimensions - an insight analysis for clinically applied remedies. Int J Med Sci. 2020;17:3125-45. https://doi.org/10.7150/ijms.50260.

25. Yang Y, Islam MS, Wang J, Li Y, Chen X. Traditional Chinese Medicine in the treatment of patients infected with 2019-New Coronavirus (SARS-CoV-2): a review and perspective. Int J Biol Sci. 2020;16:1708-17. https://doi.org/10.7150/ijbs.45538.

26. H L. Shining a Light on COVID-19's Long Shadow, Director's Page. 2021. https://www.nccih.nih.gov/about/offices/od/director/ past-messages/shining-a-light-on-covid-19s-long-shadow?nav= govd. Accessed February 242021.

27. Luo H, Tang QL, Shang YX, Liang SB, Yang M, Robinson N. et al. Can Chinese Medicine be used for prevention of Corona Virus Disease 2019 (COVID-19)? a review of Historical Classics, Research Evidence and Current Prevention Programs. Chin J Integr Med. 2020;26:243-50. https://doi.org/10.1007/s11655-0203192-6.

28. Huang F, Li Y, Leung EL, Liu X, Liu K, Wang Q. et al. A review of therapeutic agents and Chinese herbal medicines against SARSCOV-2 (COVID-19). Pharm Res. 2020;158:104929. https://doi. org/10.1016/j.phrs.2020.104929.

29. Ang L, Lee HW, Choi JY, Zhang J, Soo Lee M. Herbal medicine and pattern identification for treating COVID-19: a rapid review of guidelines. Integr Med Res. 2020;9:100407. https://doi.org/10. 1016/j.imr.2020.100407.

30. Zhang D, Zhang B, Lv JT, Sa RN, Zhang XM, Lin ZJ. The clinical benefits of Chinese patent medicines against COVID-19 based on current evidence. Pharm Res. 2020;157:104882. https:// doi.org/10.1016/j.phrs.2020.104882.

31. López-Alcalde J, Yan Y, Witt CM, Barth J. Current State of Research about Chinese Herbal Medicines (CHM) for the treatment of Coronavirus Disease 2019 (COVID-19): A Scoping Review. J Alter Complement Med. 2020;26:557-70. https://doi. org/10.1089/acm.2020.0189.

32. Zhao ZH, Zhou Y, Li WH, Huang QS, Tang ZH, Li H. Analysis of Traditional Chinese Medicine Diagnosis and Treatment Strategies for COVID-19 Based on "The Diagnosis and Treatment Program for Coronavirus Disease-2019" from Chinese Authority. Am J Chin Med. 2020;48:1035-49. https://doi.org/10.1142/ s0192415x20500500. 
33. Liu R, Zhang Y, Nicholas S, Leng A, Maitland E, Wang J. COVID-19 Vaccination Willingness among Chinese Adults under the Free Vaccination Policy. Vaccines (Basel). 2021;9. https://doi. org/10.3390/vaccines 9030292.

34. Kang JW, Kim JH, Song K, Kim SH, Yoon JH, Kim KS. Kaempferol and quercetin, components of Ginkgo biloba extract (EGb 761), induce caspase-3-dependent apoptosis in oral cavity cancer cells. Phytother Res. 2010;24:S77-82. https://doi.org/10. 1002/ptr.2913.

35. Okamoto K, Sako Y. Recent advances in FRET for the study of protein interactions and dynamics. Curr Opin Struct Biol. 2017;46:16-23. https://doi.org/10.1016/j.sbi.2017.03.010.

36. Yang H, Xie W, Xue X, Yang K, Ma J, Liang W. et al. Design of wide-spectrum inhibitors targeting coronavirus main proteases. PLoS Biol. 2005;3:e324. https://doi.org/10.1371/journal.pbio. 0030324.

37. Andi B KD, Kreitler DF, Soares AS, Shi W, Jakoncic J, Fuchs $\mathrm{MR}$, et al. Virus NSP3/NSP4A inhibitors as promising lead compounds for the design of new covalent inhibitors for SARSCoV-2 3CLpro/Mpro Protease.

38. Ratia K, Saikatendu KS, Santarsiero BD, Barretto N, Baker SC, Stevens RC. et al. Severe acute respiratory syndrome coronavirus papain-like protease: structure of a viral deubiquitinating enzyme. Proc Natl Acad Sci USA. 2006;103:5717-22. https://doi.org/10. 1073/pnas.0510851103.

39. Osipiuk J, Jedrzejczak R, Tesar C, Endres M, Stols L, Babnigg G, et al. The crystal structure of papain-like protease of SARS CoV2. https://doi.org/10.2210/pdb6W9C/pdb.

40. Kirchdoerfer RN, Ward AB. Structure of the SARS-CoV nsp12 polymerase bound to nsp7 and nsp8 co-factors. Nat Commun. 2019;10:2342. https://doi.org/10.1038/s41467-019-10280-3.

41. Yin W, Mao C, Luan X, Shen DD, Shen Q, Su H. et al. Structural basis for inhibition of the RNA-dependent RNA polymerase from SARS-CoV-2 by remdesivir. Science. 2020;368:1499-504. https://doi.org/10.1126/science.abc1560.

42. Yu IM, Oldham ML, Zhang J, Chen J. Crystal structure of the severe acute respiratory syndrome (SARS) coronavirus nucleocapsid protein dimerization domain reveals evolutionary linkage between corona- and arteriviridae. J Biol Chem. 2006;281:17134-9. https://doi.org/10.1074/jbc.M602107200.

43. Chang C, Michalska K, Jedrzejczak R, Maltseva N, Endres M, Godziks A, et al. Crystal structure of RNA binding domain of nucleocapsid phosphoprotein from SARS coronavirus 2. https:// doi.org/10.2210/pdb6VYO/pdb.

44. Walls AC, Tortorici MA, Bosch BJ, Frenz B, Rottier PJM, DiMaio F. et al. Cryo-electron microscopy structure of a coronavirus spike glycoprotein trimer. Nature. 2016;531:114-7. https://doi.org/10.1038/nature16988.

45. Walls AC, Park YJ, Tortorici MA, Wall A, McGuire AT, Veesler D. Structure, function, and antigenicity of the SARS-CoV-2 Spike Glycoprotein. Cell. 2020;181:281-92.e6. https://doi.org/10.1016/ j.cell.2020.02.058.

46. Clark HF, Gurney AL, Abaya E, Baker K, Baldwin D, Brush J. et al. The secreted protein discovery initiative (SPDI), a largescale effort to identify novel human secreted and transmembrane proteins: a bioinformatics assessment. Genome Res. 2003;13:2265-70. https://doi.org/10.1101/gr.1293003.

47. Hall DC,Jr., Ji HF. A search for medications to treat COVID-19 via in silico molecular docking models of the SARS-CoV-2 spike glycoprotein and 3CL protease. Travel Med Infect Dis. 2020;35:101646. https://doi.org/10.1016/j.tmaid.2020.101646.

48. Boukhatem MN, Setzer WN. Aromatic Herbs, Medicinal PlantDerived Essential Oils, and Phytochemical Extracts as Potential Therapies for Coronaviruses: Future Perspectives. Plants (Basel). 2020;9. https://doi.org/10.3390/plants9060800.
49. Jalali A, Dabaghian F, Akbrialiabad H, Foroughinia F, Zarshenas MM. A pharmacology-based comprehensive review on medicinal plants and phytoactive constituents possibly effective in the management of COVID-19. Phytother Res. 2021;35:1925-38. https://doi.org/10.1002/ptr.6936.

50. Akalın E, Ekici M, Alan Z, Özbir Elevli E, Yaman Bucak A, Aobuliaikemu N. et al. Traditional Chinese medicine practices used in COVID-19 (Sars-cov 2/Coronavirus-19) treatment in clinic and their effects on the cardiovascular system. Turk Kardiyol Dern Ars. 2020;48:410-24. https://doi.org/10.5543/tkda. 2020.03374.

51. Zhou J, Huang J. Current findings regarding natural components with potential Anti-2019-nCoV Activity. Front Cell Dev Biol. 2020;8:589. https://doi.org/10.3389/fcell.2020.00589.

52. Oladele JO, Ajayi EI, Oyeleke OM, Oladele OT, Olowookere BD, Adeniyi BM. et al. A systematic review on COVID-19 pandemic with special emphasis on curative potentials of Nigeria based medicinal plants. Heliyon. 2020;6:e4897. https://doi.org/10. 1016/j.heliyon.2020.e04897.

53. Adhikari B, Marasini BP, Rayamajhee B, Bhattarai BR, Lamichhane G, Khadayat K. et al. Potential roles of medicinal plants for the treatment of viral diseases focusing on COVID-19: a review. Phytother Res. 2021;35:1298-312. https://doi.org/10. 1002/ptr.6893.

54. Hoever G, Baltina L, Michaelis M, Kondratenko R, Baltina L, Tolstikov GA. et al. Antiviral activity of glycyrrhizic acid derivatives against SARS-coronavirus. J Med Chem. 2005;48:1256-9. https://doi.org/10.1021/jm0493008.

55. Vardhan S, Sahoo SK. In silico ADMET and molecular docking study on searching potential inhibitors from limonoids and triterpenoids for COVID-19. Comput Biol Med. 2020;124:103936. https://doi.org/10.1016/j.compbiomed.2020.103936.

56. Muhseen ZT, Hameed AR, Al-Hasani HMH, Ahmad S, Li G. Computational Determination of Potential Multiprotein Targeting Natural Compounds for Rational Drug Design Against SARS-COV2. Molecules. 2021;26. https://doi.org/10.3390/molecules26030674.

57. Khalil A, Tazeddinova D. The upshot of Polyphenolic compounds on immunity amid COVID-19 pandemic and other emerging communicable diseases: An appraisal. Nat Prod Bioprospect. 2020;10:411-29. https://doi.org/10.1007/s13659-020-00271-z.

58. Mani JS, Johnson JB, Steel JC, Broszczak DA, Neilsen PM, Walsh KB. et al. Natural product-derived phytochemicals as potential agents against coronaviruses: A review. Virus Res. 2020;284:197989. https://doi.org/10.1016/j.virusres.2020.197989.

59. Solnier J, Fladerer JP. Flavonoids: a complementary approach to conventional therapy of COVID-19? Phytochem Rev. 2020:1-23. https://doi.org/10.1007/s11101-020-09720-6.

60. Limanaqi F, Busceti CL, Biagioni F, Lazzeri G, Forte M, Schiavon $\mathrm{S}$, et al. Cell clearing systems as targets of polyphenols in viral infections: potential implications for COVID-19 Pathogenesis. Antioxidants (Basel). 2020;9. https://doi.org/10.3390/a ntiox9111105.

61. Zhi HJ, Zhu HY, Zhang YY, Lu Y, Li H, Chen DF. In vivo effect of quantified flavonoids-enriched extract of Scutellaria baicalensis root on acute lung injury induced by influenza A virus. Phytomedicine. 2019;57:105-16. https://doi.org/10.1016/j.phymed. 2018.12.009.

62. Huang YF, Bai C, He F, Xie Y, Zhou H. Review on the potential action mechanisms of Chinese medicines in treating Coronavirus Disease 2019 (COVID-19). Pharm Res. 2020;158:104939. https:// doi.org/10.1016/j.phrs.2020.104939.

63. Goyal RK, Majeed J, Tonk R, Dhobi M, Patel B, Sharma K. et al. Current targets and drug candidates for prevention and treatment of SARS-CoV-2 (COVID-19) infection. Rev Cardiovasc Med. 2020;21:365-84. https://doi.org/10.31083/j.rcm.2020.03.118. 
64. Su HX, Yao S, Zhao WF, Li MJ, Liu J, Shang WJ. et al. AntiSARS-CoV-2 activities in vitro of Shuanghuanglian preparations and bioactive ingredients. Acta Pharm Sin. 2020;41:1167-77. https://doi.org/10.1038/s41401-020-0483-6.

65. Consortium TCM, Achdout H, Aimon A, Bar-David E, Barr H, Ben-Shmuel A, et al. COVID Moonshot: Open Science Discovery of SARS-CoV-2 Main Protease Inhibitors by Combining Crowdsourcing, High-Throughput Experiments, Computational Simulations, and Machine Learning. bioRxiv. 2020:2020.10.29.339317. https://doi.org/10.1101/2020.10.29.339317.

66. Tallei TE, Tumilaar SG, Niode NJ, Fatimawali, Kepel BJ, Idroes $\mathrm{R}$, et al. Potential of plant bioactive compounds as SARS-CoV-2 Main Protease (M(pro)) and Spike (S) Glycoprotein Inhibitors: A Molecular Docking Study. Sci (Cairo). 2020;2020:6307457. https://doi.org/10.1155/2020/6307457

67. Lowe H, Steele B, Bryant J, Toyang N, Ngwa W. Non-cannabinoid metabolites of cannabis sativa L. with Therapeutic Potential. Plants (Basel). 2021;10. https://doi.org/10.3390/plants10020400.

68. Elsohly MA, Slade D. Chemical constituents of marijuana: the complex mixture of natural cannabinoids. Life Sci. 2005;78:539-48. https://doi.org/10.1016/j.lfs.2005.09.011.

69. Pollastro F, Minassi A, Fresu LG. Cannabis phenolics and their bioactivities. Curr Med Chem. 2018;25:1160-85. https://doi.org/ 10.2174/0929867324666170810164636.

70. Sexton M. Cannabis in the Time of Coronavirus Disease 2019: The Yin and Yang of the Endocannabinoid System in Immunocompetence. J Alter Complement Med. 2020;26:444-8. https:// doi.org/10.1089/acm.2020.0144.

71. Sainz-Cort A, Heeroma JH. The interaction between the endocannabinoid system and the renin angiotensin system and its potential implication for COVID-19 infection. J Cannabis Res. 2020;2:23. https://doi.org/10.1186/s42238-020-00030-4.

72. Anil SM, Shalev N, Vinayaka AC, Nadarajan S, Namdar D, Belausov E. et al. Cannabis compounds exhibit anti-inflammatory activity in vitro in COVID-19-related inflammation in lung epithelial cells and pro-inflammatory activity in macrophages. Sci Rep. 2021;11:1462. https://doi.org/10.1038/s41598-021-81049-2.

73. Stasiłowicz A, Tomala A, Podolak I, Cielecka-Piontek J. Cannabis sativa L. as a Natural Drug Meeting the Criteria of a Multitarget Approach to Treatment. Int J Mol Sci. 2021;22. https://doi.org/10. 3390/ijms22020778.

74. Khodadadi H, Salles ÉL, Shin E, Jarrahi A, Costigliola V, Kumar $P$. et al. A potential role for cannabichromene in modulating TRP channels during acute respiratory distress syndrome. J Cannabis Res. 2021;3:45. https://doi.org/10.1186/s42238-021-00101-0.

75. Malinowska B, Baranowska-Kuczko M, Kicman A, Schlicker E. Opportunities, Challenges and Pitfalls of Using Cannabidiol as an Adjuvant Drug in COVID-19. Int J Mol Sci. 2021;22. https://doi. org/10.3390/ijms22041986.

76. Khodadadi H, Salles ÉL, Jarrahi A, Chibane F, Costigliola V, Yu JC. et al. Cannabidiol modulates cytokine storm in acute respiratory distress syndrome induced by simulated viral infection using synthetic RNA. Cannabis Cannabinoid Res. 2020;5:197-201. https://doi.org/10.1089/can.2020.0043.

77. Paland N, Pechkovsky A, Aswad M, Hamza H, Popov T, Shahar E. et al. The Immunopathology of COVID-19 and the Cannabis
Paradigm. Front Immunol. 2021;12:631233. https://doi.org/10. 3389/fimmu.2021.631233.

78. Nguyen LC, Yang D, Nicolaescu V, Best TJ, Ohtsuki T, Chen SN, et al. Cannabidiol inhibits SARS-CoV-2 replication and promotes the host innate immune response. bioRxiv. 2021. https://doi.org/ 10.1101/2021.03.10.432967.

79. Suryavanshi SV, Kovalchuk I, Kovalchuk O. Cannabinoids as key regulators of inflammasome signaling: a current perspective. Front Immunol. 2020;11:613613. https://doi.org/10.3389/fimmu.2020. 613613.

80. Sarkar I, Sen G, Bhattacharya M, Bhattacharyya S, Sen A. In silico inquest reveals the efficacy of Cannabis in the treatment of post-Covid-19 related neurodegeneration. J Biomol Struct Dyn. 2021:1-10. https://doi.org/10.1080/07391102.2021.1905556.

81. Hill KP. Cannabinoids and the Coronavirus. Cannabis Cannabinoid Res. 2020;5:118-20. https://doi.org/10.1089/can.2020.0035.

82. Wang B, Kovalchuk A, Li D, Rodriguez-Juarez R, Inytskyy Y, Kovalchuk I. et al. In search of preventive strategies: novel highCBD Cannabis sativa extracts modulate ACE2 expression in COVID-19 gateway tissues. Aging (Albany NY). 2020;12:22425-44. https://doi.org/10.18632/aging.202225.

83. Esposito G, Pesce M, Seguella L, Sanseverino W, Lu J, Corpetti C. et al. The potential of cannabidiol in the COVID-19 pandemic. Br J Pharm. 2020;177:4967-70. https://doi.org/10.1111/bph. 15157.

84. Jha NK, Sharma C, Hashiesh HM, Arunachalam S, Meeran MN, Javed $H$. et al. $\beta$-Caryophyllene, a natural dietary CB2 receptor selective cannabinoid can be a candidate to target the trinity of infection, immunity, and inflammation in COVID-19. Front Pharm. 2021;12:590201. https://doi.org/10.3389/fphar.2021. 590201.

85. Ngwa W, Kumar R, Thompson D, Lyerly W, Moore R, Reid TE, et al. Potential of Flavonoid-Inspired Phytomedicines against COVID-19. Molecules. 2020;25. https://doi.org/10.3390/ molecules25112707.

86. Shover CL, Humphreys K. Debunking Cannabidiol as a Treatment for COVID-19: Time for the FDA to Adopt a Focused Deterrence Model?. Cureus. 2020;12:e8671. https://doi.org/10. 7759/cureus.8671.

87. Onaivi ES, Sharma V. Cannabis for COVID-19: can cannabinoids quell the cytokine storm?. Future Sci OA. 2020;6:Fso625. https:// doi.org/10.2144/fsoa-2020-0124.

88. Dabeek WM, Marra MV. Dietary Quercetin and Kaempferol: Bioavailability and Potential Cardiovascular-Related Bioactivity in Humans. Nutrients. 2019;11. https://doi.org/10.3390/ nu11102288.

89. Gao Y, Yan L, Huang Y, Liu F, Zhao Y, Cao L. et al. Structure of the RNA-dependent RNA polymerase from COVID-19 virus. Science. 2020;368:779-82. https://doi.org/10.1126/science.abb7498.

90. Yan R, Zhang Y, Li Y, Xia L, Guo Y, Zhou Q. Structural basis for the recognition of SARS-CoV-2 by full-length human ACE2. Science. 2020;367:1444-8. https://doi.org/10.1126/science. abb2762.

91. Li F, Li W, Farzan M, Harrison SC. Structure of SARS coronavirus spike receptor-binding domain complexed with receptor. Science. 2005;309:1864-8. https://doi.org/10.1126/science.1116480. 